\title{
Health measures of Eeyouch (Cree) who are eligible to participate in the on-the-land Income Security Program in Eeyou Istchee (northern Quebec, Canada)
}

\author{
Robert J. Moriarity ${ }^{1 *}$ (D), Aleksandra M. Zuk,2, Eric N. Liberda ${ }^{3}$ and Leonard J. S. Tsuji ${ }^{1}$
}

\begin{abstract}
Background: Participation in on-the-land programs that encourage traditional cultural activities may improve health and well-being. The Income Security Program (ISP) - a financial incentive-based on-the-land program - for Eeyouch (Cree) hunters and trappers in Eeyou Istchee was created as a result of the 1975 James Bay and Northern Quebec Agreement to help mitigate the effects of hydroelectric development on the Cree people of northern Quebec, Canada. Beyond the ISP's financial incentives, little is known about the health measures of those who are eligible to participate in the ISP (i.e. spent $\geq 120$ days on-the-land during the previous year). Therefore, this paper's objective was to assess the health measures of northern Quebec Cree, who were eligible for participation in the ISP.

Methods: Using participant data $(n=545)$ compiled from the Nituuchischaayihtitaau Aschii Multi-Community Environment-and-Health Study, we assessed 13 different health measures in generalized linear models with the independent variable being the eligibility to participate in the ISP.

Results: Participants in the present study who were eligible for the ISP had significantly higher levels of vigorous and moderate activity per week, and higher concentrations of omega-3 polyunsaturated fatty acids in the blood compared to those ineligible for the ISP (i.e. spent $\leq 119$ days on-the-land during the previous year). Encouragingly, following model adjustment for age and sex, participants eligible for the ISP did not have higher blood concentrations of mercury than those who were not eligible for the ISP.

Conclusions: Our results suggest that the participants eligible for participation in the ISP are likely to be healthier than those who are ineligible to participate - and are promising for on-the-land programs for Indigenous peoples beyond a financial incentive - with no apparent higher risk of increasing contaminant body burden through traditional on-theland-activities (e.g. fish consumption).
\end{abstract}

Keywords: Income Security Program, Indigenous Health, Cree peoples, Traditional cultural activities, Physical activity, Traditional diet, on-the-land activities

\footnotetext{
* Correspondence: rob.moriarity@mail.utoronto.ca

'Department of Physical and Environmental Sciences, SW151 University of Toronto, Toronto, ON M1C 1A4, Canada

Full list of author information is available at the end of the article
}

C C The Author(s). 2021 Open Access This article is licensed under a Creative Commons Attribution 4.0 International License, which permits use, sharing, adaptation, distribution and reproduction in any medium or format, as long as you give appropriate credit to the original author(s) and the source, provide a link to the Creative Commons licence, and indicate if changes were made. The images or other third party material in this article are included in the article's Creative Commons licence, unless indicated otherwise in a credit line to the material. If material is not included in the article's Creative Commons licence and your intended use is not permitted by statutory regulation or exceeds the permitted use, you will need to obtain permission directly from the copyright holder. To view a copy of this licence, visit http://creativecommons.org/licenses/by/4.0/ The Creative Commons Public Domain Dedication waiver (http://creativecommons.org/publicdomain/zero/1.0/) applies to the data made available in this article, unless otherwise stated in a credit line to the data. 


\section{Background}

Participating in traditional cultural activities and being on-the-land are important aspects of the Indigenous way of life $[114,115]$. Traditional cultural activities can include hunting, fishing, gathering, trapping, and orally passing down traditional knowledge to younger generations $[63,117]$. Hunting, fishing, and gathering also help offset the higher cost of foods in Indigenous communities, especially northern communities in Canada [39, 81, 116]. Importantly, studies have also shown that being on-the-land, that is, participating in traditional activities, may improve health and well-being $[1,36,45,46,58$, 79]. For example, approximately $70 \%$ of Alaskan Native adults who engaged in at least one traditional cultural activity per year self-reported benefits to their well-being as a result [92, 93]. Additionally, Alaskan Native women used the phrase 'keeping busy' to describe their perceptions of health and well-being, in the context of being on-the-land - while eating traditional food and respecting Elders and nature [45]. Further, in a smallprospective-cohort study [97] of eastern James Bay Cree Peoples (Quebec, Canada) with type 2 diabetes - 25 participants spent 3 months on-the-land, while 26 controls remained in the community - on-the-land living had positive effects on various health measures (e.g. activity increased, weight decreased, blood glucose decreased). Thus, programs that encourage traditional cultural activities on-the-land may improve health and well-being. One such program is the Income Security Program (ISP), available to the First Nations Cree Peoples of the Eeyou Istchee region, northern Quebec, Canada.

The ISP for Cree hunters and trappers in Eeyou Istchee was established by the James Bay and Northern Quebec Agreement (JBNQA) nearly 46 years ago "to provide an income guarantee and benefits...for Cree people who wish to pursue harvesting activities as a way of life" (section 30.1.1, [48]). This on-the-land program was negotiated to help mitigate hydroelectric mega-projects' effects on the Cree Peoples traditional homelands, especially on their way of life and connection to the land [49]. For eligible participation in the ISP - participation is optional - community members of Eeyou Istchee are required to spend at least 120 days on-the-land involved in traditional cultural activities, such as, fishing and wildlife harvesting [98, 112]. Cree Peoples who are eligible for participation in the ISP are paid quarterly following interviews with the Cree Hunters and Trappers Income Security Board representatives where participants report their on-the-land activity and their benefits are calculated [24]. According to Altman and Cochrane [3], participating in an income-incentive program to support on-the-land activities has three benefits: (1) participants are paid no matter what type of harvest they obtain for any reason outside of their control; (2) it promotes wildlife management in the community by participants who are also community members; and (3) the program provides incentives for custodial stewardship of individual community traditional lands. To date, the ISP is the longest-running on-the-land financial incentive program in the world. However, there is a paucity of studies, beyond the financial incentive, of health measures for these types of on-the-land programs. Consequently, an assessment of the potential benefits of participation in on-theland-incentive programs, such as the ISP, which may promote health and well-being through traditional cultural activities, is warranted, particularly from a health measures perspective. Therefore, the purpose of the present study was to assess several health measures of Cree Peoples who were eligible for participation in the ISP and assess if their potential participation based on their eligibility could be beneficial, beyond a financial standpoint, compared to the Cree Peoples who were not eligible for participation in the ISP.

\section{Methods \\ Study region}

There are approximately 18,000 residents of Eeyou Istchee (Fig. 1) who speak at least one of the Cree, French or English languages [25, 106]. Traditional cultural activities in this region vary based on the community's location as four communities are on the coast, and the other five are inland, where approximately $62 \%$ of the total population live in coastal communities and $48 \%$ live inland. The region is primarily accessible by road (paved and unpaved), air, and water, while the most northern coastal community of approximately 800 residents is only accessible by air or water.

\section{Data}

The Nituuchischaayihtitaau Aschii Multi-Community Environment-and-Health Study in Eeyou Istchee [NA study] [75] was a seven-community study (exclusive of the two community pilot studies) carried out in the Eeyou Istchee region (Fig. 1) between 2005 and 2009 that investigated environmental health concerns of 1405 participants. Prior to the start of the multi-community study in 2005, "A Needs and Feasibility Study" was conducted with the remaining seven Cree Nations that would eventually take part in the multi-community study [76]. The main objectives of the Needs-and-Feasibility Study were to: "Carry out an intensive consultation process with all the Cree communities-and entities to determine local environment-and-health-issues...Develop a detailed study proposal that includes the information and direction received during the local consultations." ([77], p. 2). From 2003 to 2004, consultations occurred with these regional Cree entities: the Cree Trappers' Association Executive and Board; the James Bay Advisory Committee on 


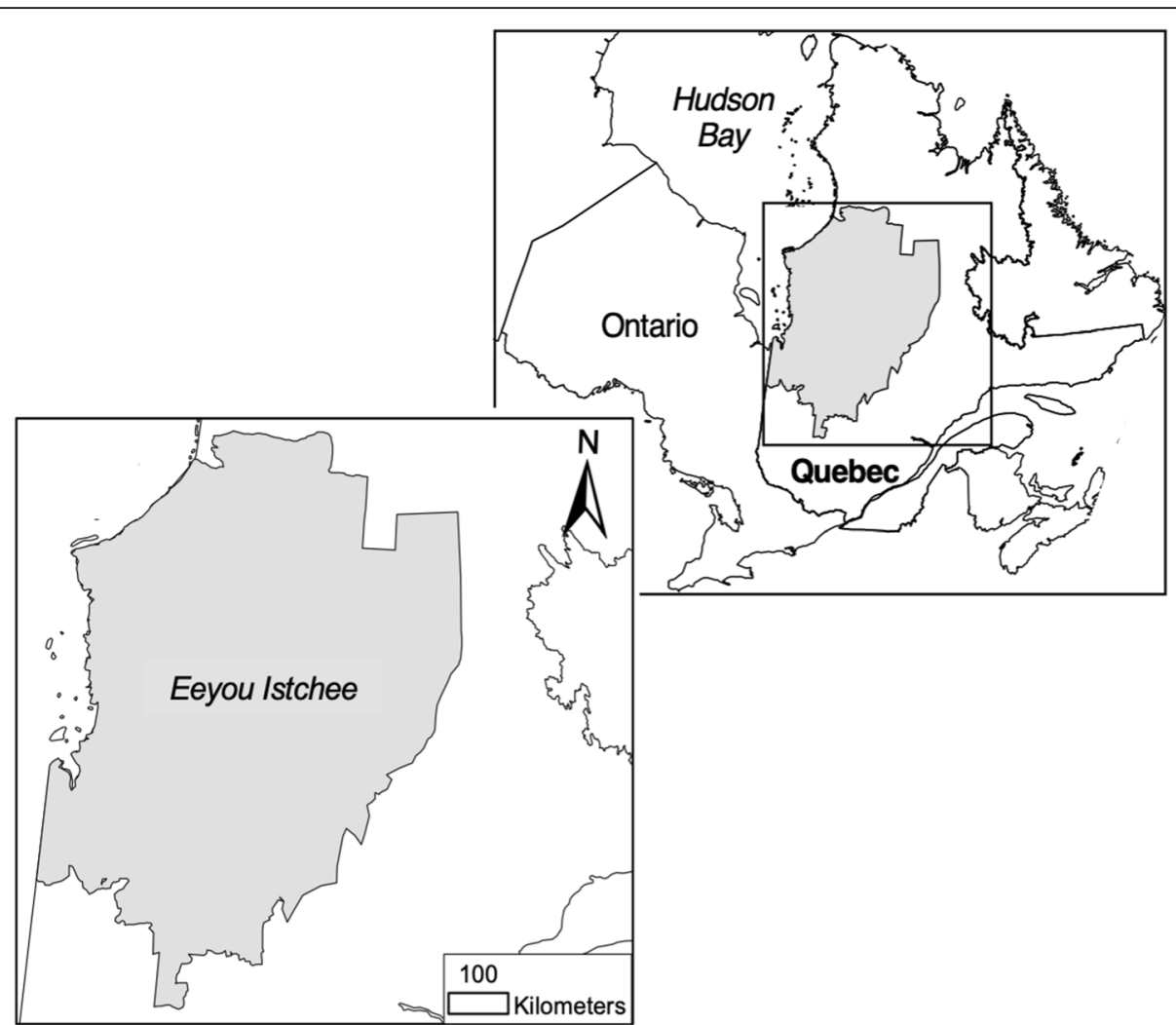

Fig. 1 The Eeyou Istchee territory of Northern Quebec, Canada. The map depicted in Fig. 1 is wholly designed and owned by the corresponding author, Robert J. Moriarity

the Environment; and the Traditional Pursuits Division of the Cree Regional Authority [77]. Similarly, consultative meetings were held with locally-elected Cree governing bodies - that is, Chiefs and Councils - as well as with community members in the Cree Nations themselves [77]. These consultations helped to inform the proposal as presented to the funding agency [77]. It should also be noted that Chiefs and Councils formally approved the project [75]. For more information on the multi-community study population, study design, and data collection, please refer to Bonnier-Viger et al. [13] and Nieboer et al. [74, 75]. Dr. Leonard Tsuji was involved at the community level during the pilot-study and has over 30 years of experience working with James Bay Cree communities.

Ethics approval was granted by McGill University, Laval University, McMaster University, and the Cree Board of Health and Social Services of James Bay (CBHSSJB). Participants provided written informed consent in Cree, English, or French languages. Additionally, the university researchers entered a "Research and Data Use Agreement" [21] whereby the CBHSSJB was "the guardian of the Original Data" (p. 7); and "the CBHSSJB takes decisions for the benefit of the Cree participants, including the participating Cree First Nations" (p. 2). The CBHSSJB Chairperson is elected by the Cree
Nations' Peoples and is the Cree representative on the CBHSSJB Board of Directors [20]. The CBHSSJB follows the OCAP (ownership, control, access and possession) principles and the Tri- Council Policy Statement (Ethical Conduct for Research Involving Humans) [23]. Prior to sending out manuscripts for journal peer review, as per the Research and Data Use Agreement [21], draft manuscripts had to undergo a review process with the CBHSSJB Data Analysis Review Committee, and "address comments and resolve any issues raised by reviewers" (p. 26).

Our study used data from five communities in the NA study - excluding data from the two pilot studies and two additional communities as the question about participants' days spent on-the-land was not included in the questionnaire in these communities (Supplementary Figure S1). The age and sex data used in this study excluded those below the age of 15 because there were significant gaps in the NA study data for variables relevant to our study. Data for smoking status (essential for adjusting the inflammatory marker models) were also collected as a model-adjustment variable (Supplementary Figure S1). Based on this exclusion criteria, our study had $n=545$ participants from five communities where data was collected from 2005 to 2009. 
The health measures selected for analysis included: self-reported weekly activity (i.e. vigorous, moderate, and walking in hours per week (hours/week)); a proxy measure for traditional diet consumption (i.e. omega-3 polyunsaturated fatty acids in nanomoles per litre $(\mathrm{nmol} / \mathrm{L})$ [30, 119];); other lipids (i.e. total cholesterol, low-density lipoprotein (LDL) cholesterol, and high-density lipoprotein (HDL) cholesterol in $\mathrm{nmol} / \mathrm{L}$ ); three inflammatory markers (i.e. tumour necrosis factor-alpha (TNF- $\alpha$ ) and interleukin-6 (IL-6) both in picograms per millilitre ( $\mathrm{pg} /$ $\mathrm{mL}$ ), and c-reactive protein (CRP) in milligrams per litre $(\mathrm{mg} / \mathrm{L}))$; and anthropometric measures (i.e. Body Mass Index (BMI) in kilograms per square metre $\left(\mathrm{kg} / \mathrm{m}^{2}\right)$ and waist circumference in centimetres $(\mathrm{cm}))$. Data for cholesterol, LDL, HDL, TNF- $\alpha$, and IL- 6 were log-transformed. See Liberda et al. [62] for a detailed explanation of the biomarker laboratory analysis. Furthermore, blood concentrations of total mercury (nmol/L) were examined as a potential risk of being on-the-land, and the data were also log-transformed. A sensitivity analysis was also run for selenium's potential alleviation effects on mercury impacts in the regression models.

The independent variable in our study was a binary variable for eligibility for participation in the ISP. Study participants were classified as eligible if 120 days or more were spent on-the-land performing traditional cultural activities during the previous year (i.e. in the last 365 days), and ineligible if 119 days or less were spent onthe-land over the previous year. We assumed eligibility for the ISP corresponded to the potential benefits of participating in the ISP, however, this independent variable is not a direct measure of actual participation. The inclusion criteria in our dataset corresponded to a participant with known age, sex, and smoking status, and at least one of the measures under investigation (Supplementary Figure S1); thus, sample sizes are different for some variables and do not total to the overall $n$. Table 1 shows the available sample sizes of participant data observed for each dependent variable categorized by the independent variable and sex.

Table 1 Descriptive statistics of participants based on the eligibility for participation in the Income Security Program (ISP)

\begin{tabular}{|c|c|c|c|c|c|c|c|c|}
\hline \multirow[b]{3}{*}{ Variable } & \multicolumn{8}{|c|}{ Income Security Program Eligibility } \\
\hline & \multicolumn{4}{|c|}{ Ineligible to participate ( $\leq 119$ days on-the-land) } & \multicolumn{4}{|c|}{ Eligible to participate ( $\geq 120$ days on-the-land) } \\
\hline & $\begin{array}{l}\text { Male } \\
(n)\end{array}$ & $\begin{array}{l}\text { Female } \\
(n)\end{array}$ & $\begin{array}{l}\text { All } \\
(n)\end{array}$ & Mean (SD) & $\begin{array}{l}\text { Male } \\
(n)\end{array}$ & $\begin{array}{l}\text { Female } \\
(n)\end{array}$ & $\begin{array}{l}\text { All } \\
(n)\end{array}$ & Mean (SD) \\
\hline \multicolumn{9}{|l|}{ Activity (hours/week) } \\
\hline Vigorous & 78 & 71 & 149 & $1.52(1.80)$ & 19 & 14 & 33 & $3.50(2.43)$ \\
\hline Moderate & 101 & 124 & 225 & $2.03(2.04)$ & 24 & 22 & 46 & $3.71(2.95)$ \\
\hline Walking & 99 & 113 & 212 & $1.87(2.78)$ & 23 & 14 & 37 & $1.70(1.84)$ \\
\hline \multicolumn{9}{|l|}{ Anthropometry } \\
\hline $\mathrm{BMI}\left(\mathrm{kg} / \mathrm{m}^{2}\right)$ & 172 & 272 & 444 & $32.98(7.37)$ & 45 & 37 & 82 & $34.22(8.80)$ \\
\hline Waist circumference $(\mathrm{cm})$ & 173 & 272 & 445 & $107.99(15.91)$ & 45 & 37 & 82 & $112.20(14.33)$ \\
\hline \multicolumn{9}{|l|}{ Traditional diet (nmol/L) } \\
\hline Omega-3 & 108 & 137 & 245 & $6.20(1.51)$ & 25 & 17 & 42 & $7.66(1.61)$ \\
\hline \multicolumn{9}{|l|}{ Lipid (nmol/L) } \\
\hline Cholesterol & 173 & 273 & 446 & $0.73(0.07)$ & 45 & 37 & 82 & $0.75(0.07)$ \\
\hline LDL & 172 & 267 & 439 & $0.53(0.10)$ & 42 & 37 & 79 & $0.56(0.09)$ \\
\hline $\mathrm{HDL}$ & 173 & 273 & 446 & $0.35(0.06)$ & 45 & 37 & 82 & $0.36(0.05)$ \\
\hline \multicolumn{9}{|l|}{ Inflammatory Marker ${ }^{\mathbf{b}}$} \\
\hline TNF-a (pg/mL) & 108 & 137 & 245 & $2.94(2.20)$ & 25 & 18 & 43 & $2.77(3.04)$ \\
\hline IL-6 (pg/mL) & 108 & 137 & 245 & $2.42(1.99)$ & 25 & 18 & 43 & $2.95(1.79)$ \\
\hline CRP (mg/L) & 108 & 137 & 245 & $2.58(3.17)$ & 25 & 18 & 43 & $3.30(2.59)$ \\
\hline \multicolumn{9}{|l|}{ Contaminant $^{\mathrm{b}}(\mathrm{nmol} / \mathrm{L})$} \\
\hline Blood $[\mathrm{Hg}]$ & 173 & 273 & 446 & $15.57(3.66)$ & 45 & 37 & 82 & $63.94(3.14)$ \\
\hline Age mean (SD) & 34.47 (15.74) & $34.12(34)$ & 34.26 (15.49) & & $50.32(18.03)$ & 55.40 (15.04) & $52.78(16.76)$ & \\
\hline
\end{tabular}




\section{Statistical analysis}

Descriptive statistics of the variables are reported as arithmetic means and standard deviations (SD) - unless otherwise stated in Table 1.

Unadjusted-regression models with only one of the health measure variables and multivariable regression models using the same health measure variables, adjusted for age and sex, were carried out to assess the potential associations of ISP eligibility status of each participant with the health measures. Age and sex were included as covariates in the adjusted model as methylmercury is bioaccumulative [8] and men are more likely to be hunters and fishers compared to women [78]. Furthermore, smoking status was used to adjust the inflammatory marker models in addition to age and sex [61]. All models were checked for fit and strength, and the statistical analyses for our study were carried out in $\mathrm{R}$ version 3.6.2 [91]. Statistical significance was set at $p<0.05$.

\section{Results}

\section{Descriptive results}

The overall mean age of Cree Peoples eligible for participation in the ISP program is approximately 53 years old compared to 34 years old for ineligible participants, and those who are eligible to participate in the ISP are more frequently males. Table 1 displays the means and standard deviations from the health measure variables categorized by the ISP eligibility variable. The table also presents the differences for each variable between eligible and ineligible participants for the ISP.

\section{Regression modelling}

Unadjusted and adjusted model beta coefficients from the regression models between the health measure variables and eligibility to participate in the ISP are presented in Table 2. From the adjusted models of eligible ISP participants, the results were significantly higher for vigorous $(\beta=1.623$ (95\% CI: $0.814-2.431), p<0.001$ ) and moderate activities ( $\beta=1.556$ (95\% CI: $0.780-2.333$ ), $p<0.001$ ), but not walking (Table 2). Cree Peoples eligible for participation in the ISP had a significantly higher association with omega- 3 polyunsaturated fatty acids ( $\beta=0.534$ (95\% CI: $0.188-0.879), p=0.003$ ) compared to those Cree participants ineligible for the ISP (Table 2). Cree Peoples who were eligible for participation in the ISP were not statistically different from ineligible participants for the ISP for total cholesterol, LDL, and HDL. As well, no significant results were found for inflammatory markers TNF- $\alpha$, IL-6, and CRP, or anthropometrics (i.e. BMI or waist circumference). For Cree Peoples who were eligible to participate in the ISP, their blood concentration of total mercury was not significantly higher than those ineligible to participate in the ISP, after adjusting for age and sex. The sensitivity analysis with selenium was not significant and did not affect the regression model result for mercury impacts (Supplementary Table S1).

\section{Discussion}

Traditional on-the-land cultural activities have been recognized in several studies as being vital to health and well-being for those who participated [42, 63, 82, 96, 126], but quantitative studies including health measures are lacking. Our findings show that Cree Peoples who are eligible for participation in the ISP reported a higher level of physical activity (i.e. vigorous and moderate activities) and had higher levels of omega-3 polyunsaturated fatty acids (an indicator of traditional food consumption), and similar blood concentrations of mercury compared to those ineligible for participation following model adjustment. Interestingly, in nonIndigenous populations the importance of greenspace $[65,68,70,120,128]$ and water [28]; Horizon 2020 "Blue Health" project; [125] has been recognized. Additionally, the health and wellbeing of Indigenous Peoples living in an urban environment is an emerging field [43].

\section{Activity levels and anthropometrics}

Programs that include physical activities based in Indigenous communities have yielded positive results, such as, decreased obesity, improved type 2 diabetes status and a reduction of cardiovascular diseases $[4,16,34,52,53,59$, 102]. Our study demonstrates that Cree Peoples, who were eligible for participation in the ISP, had higher levels of vigorous and moderate physical activity over those Cree Peoples who were ineligible for participation. These results are similar to those of Robinson et al. [97], who reported in a prospective cohort study with the James Bay Cree Peoples that participants were more active when onthe-land, and more active than a community-based control group of Cree Peoples in Eeyou Istchee. An increase in moderate-to-vigorous physical activity may increase life longevity, and be cardioprotective $[60,94,108]$. As a result, there has been a trend to include traditional cultural activities in programs for Indigenous communities, because the potential benefits of traditional cultural activities go beyond physical health (e.g. mental health and wellbeing) $[26,47,103,107,123]$.

Interestingly, our study did not demonstrate improvement in BMI or waist circumference of participants eligible for the ISP even though previous studies demonstrated some improvement in various anthropometric measures with increased physical activity [14, 38, 99]. In the Robinson et al. [97] study, the authors reported that the mean BMI for the on-the-land group was significantly lower than that of the community-based control group, but within the onthe-land group post-measures for weight were not 
Table 2 Linear regression model results assessing the association of eligibility to participate in the Income Security Program (ISP) with specific health measures

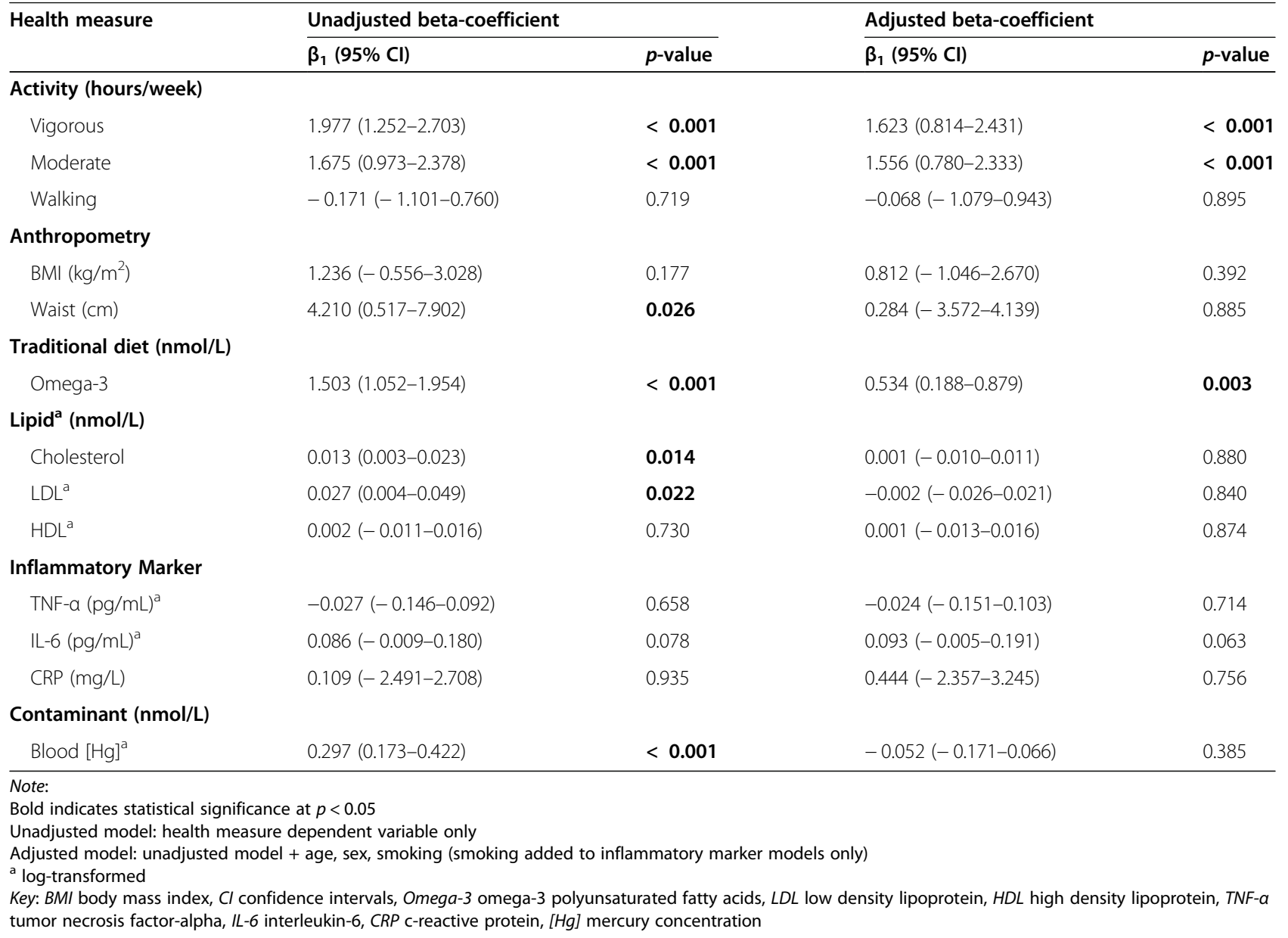

significant. Nevertheless, participation in the ISP program promotes both vigorous and moderate activities in landbased traditional cultural activities - while supplementing income - an additional benefit. Increased physical activity as a result of on-the-land programs, like the ISP, are also successful because they are rooted in the local culture and provide a meaningful way of engaging in traditional cultural activities $[11,86,111]$.

\section{Traditional diet (omega-3 polyunsaturated fatty acids)}

Diet is a unique and essential feature of the traditional cultural lifestyle for the Cree Peoples of northern Quebec, particularly the dietary composition of fats and fat components, which are considerably different from a western diet [10, 27, 29, 50, 51]. It has long been established that Indigenous community members in northern regions who consume traditional foods high in omega-3 polyunsaturated fatty acids have a significantly reduced risk of vascular diseases [6, 7, 29, 32]. Studies have demonstrated that when Indigenous community members revert to a traditional cultural lifestyle - even for intermittent periods - their risk of type 2 diabetes and cardiometabolic problems decreases significantly because animals available to the hunter and/or trapper are low in undesirable fat with higher levels of beneficial fatty acids $[58,69,78,79,83$, 88]. In our study, we determined that those eligible for participation in the ISP have significantly higher omega-3 polyunsaturated fatty acid levels compared to those ineligible for the ISP, which likely indicates that eligible participants are eating more fish, as fish is highest in omega-3 polyunsaturated fatty acids [88]. Omega-3 polyunsaturated fatty acids are known to have myriad health benefits, namely reducing cardiovascular diseases, cholesterol and LDL, and having anti-inflammatory and neurologically protective effects [29, 31, 64, 100, 121]. Furthermore, increased levels can even be associated with improved mental well-being [57]. Although omega-3 polyunsaturated fatty acids are found in wild game meats [104], land-based animals and birds native to this region tend to have higher levels of omega-6 polyunsaturated fatty acids [89, 95], which suggests that the increased levels of omega-3 polyunsaturated fatty acids are from the consumption of fish 
for those eligible to participate in the ISP. This finding is important because eligible participants are engaging in traditional cultural activities and benefit from an increase in healthy dietary fat.

Lipids (Total cholesterol, LDL cholesterol, HDL cholesterol) Increased cholesterol and LDL levels are associated with a higher risk of vascular events (e.g. myocardial infarction, stroke, or occlusive vascular diseases). These vascular events are typically a result of consuming foods of low nutritional value related to a westernized diet, or cooking methods that promote the use of unhealthy fats $[5,15,44,67,110]$. Lifestyle and genetics may also increase cholesterol and LDL levels $[41,55,66]$. Given the increased blood level of omega-3 polyunsaturated fatty acids for participants eligible for the ISP in the present study - and the higher levels of vigorous and moderate physical activity - we expected to see a decrease in cholesterol and LDL for eligible participants of the ISP compared to those ineligible. However, our results did not show this, as unadjusted and adjusted models were nonsignificant. Perhaps the cross-sectional design of the study contributed to this non-association.

Increased HDL levels are related to a traditional cultural diet, as Young [129] demonstrated in a culturally similar Indigenous population; since eligible participants for the ISP are more likely to consume traditional foods containing beneficial dietary fatty acids and other nutritive elements, it would be thought that those eligible for the ISP would have significantly higher HDL levels. Higher levels of HDL are associated with lower levels of cholesterol and LDL, and therefore, there is an assumed lower risk of occlusive vascular events and other cardiovascular health problems in people with optimal HDL [40, 67, 127]. However, our study results demonstrated no evidence of higher HDL levels for Cree Peoples eligible for participation in the ISP compared to those ineligible for participation in ISP. Again, we believe this non-significant result may be a consequence of the cross-sectional nature of the data collection.

\section{Inflammatory markers}

Inflammation in the human body can be examined through markers in the blood that indicate there is either acute or chronic inflammation and may indicate specific illness or disease, or an exposure-response to a xenobiotic [37, 124]. The cytokine TNF- $\alpha$ is a proinflammatory marker, and is involved in acute or chronic inflammation in the human body $[90,122]$. IL-6 is an inflammatory cytokine that can act as a defence mechanism, and be an indicator of acute or chronic inflammation [35]. Furthermore, CRP, an acute-phase protein synthesized in hepatocytes mainly in response to IL-6, is a predominant marker of acute inflammation rather than chronic inflammation $[85,105]$. All of these inflammatory markers may increase due to internal or external stimulus and are associated to many different exposures, risk factors, or illnesses of the human body (e.g. obesity, cancer, diabetes) $[9,87,118]$.

In our study, the results for inflammatory markers were not significant between groups. Perhaps, a lack of differences of inflammatory markers between groups in our study could be related to physical activity intensity, which is known to cause acute inflammation in the human body up to $24 \mathrm{~h}$ following activity - especially if the activity is moderate or vigorous $[33,54,84,101]$. We found that Cree Peoples eligible to participate in the ISP had increased levels of moderate and vigorous activity, so there could be an association to increased inflammation as a result. However, we are unable to fully confirm this latter association as we do not have information regarding the exact timeframe from when the participant was last on the land, and when they had their blood sample drawn for analyses of inflammatory markers.

When investigating the variables used to adjust the inflammatory marker regression models, we found that smoking was the only significant variable associated with inflammation, which suggests that those who smoke are more likely to have increased levels of TNF- $\alpha$, IL- 6 , and CRP $[2,56,80]$. Furthermore, those who are on-the-land 120 days or more per year, and therefore eligible for participation in the ISP, may have increased exposure to wood smoke from burning wood for heating and cooking, which is known to increase inflammatory marker levels upon exposure [12, 73, 109].

\section{Mercury}

Exposure to mercury from the environment, methylmercury from fish consumption mainly, has the potential for neurotoxic effects in humans [17-19]. Previous studies of methylmercury in the study region found that certain species of fish and community location in the study region [71, 72] influenced the risk of being exposed to higher levels of methylmercury. The consumption of medium and large-sized predatory fish, and participants who reside in communities nearby to high-intensity industrial land use on traditional homelands were at the greatest possibility for exposure to methylmercury according to those studies. Encouragingly, our study results indicate that Cree Peoples who are eligible to participate in the ISP, do not have increased blood concentrations of mercury compared to those who are ineligible to participate in the ISP. This finding is noteworthy because we assumed that those who spend more time on the land may have been eating more fish; thus, participants would be expected to have a higher body burden of mercury even after age-adjustment, but this was not the case. Nonetheless, we encourage community members to follow fish 
consumption recommendations as advised by the CBHSSJB [22] to minimize mercury exposure.

\section{Limitations}

The use of data from a cross-sectional study design was a limitation, and the type of data collected limited our ability to adjust models beyond age, sex and smoking status (for inflammatory markers only). Some variables of interest had missing data; thus, sample sizes for some variables were limited. The limitations above may have also influenced the results of the linear models. Additionally, this study addresses a knowledge gap, but only from a non-Indigenous health measures perspective. Ideally, Indigenous measures of health and well-being should have been collected (e.g. the vertical and horizontal transmission of Indigenous knowledge, the re-establishing and strengthening of social networks, and the general feeling of wellness out on-the-land [113]). Nonetheless, the relatively large overall sample sizes of this study for an Indigenous nation, and the evaluation of the longest continuously running on-the-land intervention globally is unique.

\section{Conclusions}

We present novel cross-sectional results of health measures for northern Quebec First Nations Cree Peoples who are eligible to participate in the on-the-land ISP. The health measures results were promising for those eligible to participate in the ISP. Specifically, higher levels of vigorous and moderate physical activity and higher levels of omega-3 polyunsaturated fatty acids for individuals who were eligible to participate were found while no differences in mercury blood concentrations between Cree Peoples who were eligible compared to those ineligible to participate in the ISP were found. Therefore, the results of our study encourage on-theland traditional cultural activities for Cree Peoples - and other Indigenous peoples - and support on-the-land mitigation and/or intervention activities to ensure their health and well-being when on-the-land.

\section{Abbreviations}

BMI: Body mass index; Cl: Confidence interval; CRP: C-reactive protein; HDL: High-density lipoprotein; IL-6: Interleukin-6; ISP: Income Security Program; JBNQA: James Bay and Northern Quebec Agreement; LDL: Lowdensity lipoprotein; NA Study: Nituuchischaayihtitaau Aschii Multi-Community Environment-and-Health Study in Eeyou Istchee; TNF-a: Tumour necrosis factor alpha

\section{Supplementary Information}

The online version contains supplementary material available at https://doi. org/10.1186/s12889-021-10654-7.

Additional file 1.

\section{Acknowledgements}

We thank those community members of Eeyou Istchee who participated in the NA study, the authors and staff who wrote the report and handled a large volume of technical data, and the team at the Cree Board of Health and Social Services of James Bay for their valuable input into the manuscript. We also thank C. Boisvert-Huneault (McGill University Health Centre) for his comprehensive draft revisions. This manuscript was initially reviewed by the Cree Board of Health and Social Services of James Bay prior to journal peer review. This scientific communication is a report from Nituuchischaayihtitaau Aschii: A Multi-Community Environment and-Health Study in Eeyou Istchee supported by the Eeyou people of northern Quebec, the Cree First Nations, and the Cree Board of Health and Social Services of James Bay.

\section{Authors' contributions}

RJM, AMZ, and LJST were responsible for study conception and design. RJM was responsible for analysis; RJM, AMZ, LJST, and ENL contributed to interpretation of results. RJM drafted original manuscript, while RJM, AMZ, LST and ENL drafted final manuscript. All authors provided editorial feedback and approved the final manuscript.

\section{Authors' information}

Robert J. Moriarity is an Indigenous environmental health researcher and doctoral candidate at the University of Toronto (Toronto, Ontario, Canada). His research examines the interactions of the environment and Indigenous health and well-being.

Aleksandra M. Zuk is an Assistant Professor in the Faculty of Health Sciences, School of Nursing, Queen's University (Kingston, Ontario, Canada). Her research interests include Indigenous health, and the aetiology of chronic diseases, specifically cardiometabolic risk factors.

Eric N. Liberda is an Associate Professor and the Associate Director in the School of Occupational and Public Health, Ryerson University (Toronto, Ontario, Canada). His research focuses on environmental health, toxicology, chronic diseases, and Indigenous health issues.

Leonard J.S. Tsuji is a Professor of environment and health at the University of Toronto (Toronto, Ontario, Canada). His research focuses on the interrelationships between the environment, health, and wellbeing, especially in Indigenous communities.

\section{Funding}

Financial contributions from the Niskamoon Corporation (agreement number 2005.06) supported the study design and data collection where additional funding support was provided by the Canadian Institutes of Health Research (FRN 156396) for data analyses, writing of the manuscript, and paper publication. Neither sponsor beyond funding support had a role in analysis, interpretation of data or in writing the manuscript.

\section{Availability of data and materials}

All data that support the findings of this study are retained with the Cree Board of Health and Social Services of James Bay. The data are not publicly available or available upon request because they contain participants' confidential health data.

\section{Declarations}

Ethics approval and consent to participate

Participants in the NA study provided written informed consent in Cree, English, or French languages, and ethics approval was granted by McGill University, Laval University, McMaster University, and the Cree Board of Health and Social Services of James Bay. A research and data use agreement between the University of Toronto, Ryerson University and the Cree Board of Health and Social Services of James Bay allowed for the use of de-identified data. Administrative permission was given to access and use the data in this study, but no administrative permission to data that identified participants was allowed. 


\section{Competing interests}

The authors declare that they have no known competing financial interests or personal relationships that could have appeared to influence the work reported in this paper.

\section{Author details}

'Department of Physical and Environmental Sciences, SW151 University of Toronto, Toronto, ON M1C 1A4, Canada. ${ }^{2}$ School of Nursing, Queen's University, Kingston, ON, Canada. ${ }^{3}$ School of Occupational and Public Health, Ryerson University, Toronto, ON, Canada.

\section{Received: 30 September 2020 Accepted: 18 March 2021} Published online: 31 March 2021

\section{References}

1. Adelson N. "Being alive well": health and the politics of Cree well-being (Vol. 16). Toronto: University of Toronto Press; 2000.

2. Aldaham S, Foote JA, Chow H-HS, Hakim IA. Smoking status effect on inflammatory markers in a randomized trial of current and former heavy smokers. Int J Inflamm. 2015;2015:1-6. https://doi.org/10.1155/2015/439396.

3. Altman JC, Cochrane M. CAEPR Discussion Paper, vol. 247; 2003. p. 23.

4. Anand SS, Davis AD, Ahmed R, Jacobs R, Xie C, Hill A, et al. A family-based intervention to promote healthy lifestyles in an Aboriginal community in Canada. Can J Public Health. 2007;98(6):447-52. https://doi.org/10.1007/ BF03405436.

5. Austin MA, Breslow JL, Hennekens CH, Buring JE, Willett WC, Krauss RM. Low-density lipoprotein subclass patterns and risk of myocardial infarction. Jama. 1988;260(13):1917-21. https://doi.org/10.1001/jama.1988.0341013012 5037.

6. Bang HO, Dyerberg J, Hjørne N. The composition of food consumed by Greenland Eskimos. Acta Med Scand. 1976;200(1-2):69-73. https://doi.org/1 0.1111/j.0954-6820.1976.tb08198.x.

7. Bang HO, Dyerberg J, Sinclair HM. The composition of the Eskimo food in north western Greenland. Am J Clin Nutr. 1980;33(12):2657-61. https://doi. org/10.1093/ajcn/33.12.2657.

8. Barbosa AC, Jardim W, Dórea JG, Fosberg B, Souza J. Hair mercury speciation as a function of gender, age, and body mass index in inhabitants of the Negro River Basin, Amazon, Brazil. Arch Environ Contam Toxicol N Y. 2001;40:439-44. https://doi.org.myaccess.library.utoronto.ca/10.1007/s00244 0010195.

9. Bautista LE, Vera LM, Arenas IA, Gamarra G. Independent association between inflammatory markers (C-reactive protein, interleukin-6, and TNF-a) and essential hypertension. J Hum Hypertens. 2005;19(2):149-54. https://doi. org/10.1038/sj.jhh.1001785

10. Belinsky DL, Kuhnlein HV, Yeboah F, Penn AF, Chan HM. Composition of fish consumed by the James Bay Cree. J Food Compos Anal. 1996;9(2):148-62. https://doi.org/10.1006/jfca.1996.0022

11. Bersamin A, Wolsko C, Luick BR, Boyer BB, Lardon C, Hopkins SE, et al. Enculturation, perceived stress, and physical activity: implications for metabolic risk among the Yup'ik-the Center for Alaska Native Health Research Study. Ethn Health. 2014;19(3):255-69. https://doi.org/10.1080/13 557858.2012.758691.

12. Bølling AK, Pagels J, Yttri KE, Barregard L, Sallsten G, Schwarze PE, et al. Health effects of residential wood smoke particles: the importance of combustion conditions and physicochemical particle properties. Part Fibre Toxicol. 2009;6(1):29. https://doi.org/10.1186/1743-8977-6-29.

13. Bonnier-Viger Y, Egeland GM, Dewailly E, Nieboer E, Pereg D. Technical report of Mistissini: authors; 2007.

14. Burgess CP, Johnston FH, Berry HL, McDonnell J, Yibarbuk D, Gunabarra C, et al. Healthy country, healthy people: the relationship between Indigenous health status and "caring for country". Med J Aust. 2009;190(10):567-72. https://doi.org/10.5694/j.1326-5377.2009.tb02566.x.

15. Carrera-Bastos P, Fontes-Villalba M, O'Keefe JH, Lindeberg S, Cordain L. The western diet and lifestyle and diseases of civilization. Res Rep Clin Cardiol. 2011;2:15-35.

16. Chan LC, Ware R, Kesting J, Marczak M, Good D, Shaw JT. Short term efficacy of a lifestyle intervention programme on cardiovascular health outcome in overweight indigenous Australians with and without type 2 diabetes mellitus: the healthy lifestyle programme (HELP). Diabetes Res Clin Pract. 2007;75(1):65-71. https://doi.org/10.1016/j.diabres.2006.04.012.
17. Clarkson T. Methylmercury and fish consumption: weighing the risks. Can Med Assoc J. 1998:158:1465.

18. Clarkson TW, Magos L, Myers GJ. The toxicology of mercury-current exposures and clinical manifestations. N Engl J Med. 2003;349(18):1731-7. https://doi.org/10.1056/NEJMra022471.

19. Clarkson TW, Magos L. The toxicology of mercury and its chemical compounds. Crit Rev Toxicol. 2006;36(8):609-62. https://doi.org/10.1080/104 08440600845619 .

20. Cree Board of Health and Social Services of James Bay. Public notice respecting the run-off election for CBHSSJB chairperson 2020 statement of run-off election results (November 10, 2020). Quebec: Cree Board of Health and Social Services of James Bay; 2020.

21. Cree Board of Health and Social Services of James Bay. Research and Data Use Agreement for Multi-Community Environment-and-Health Longitudinal Study in liyiyiu Aschii: Nituuchischaayihtitaau Aschii. Quebec: Cree Board of Health and Social Services of James Bay; 2005

22. Cree Board of Health and Social Services of James Bay. 2019. Healthy fish eating in Eeyou Istchee. Available: https://www.creegeoportal.ca/applica tions/mercurymap/.

23. Cree Board of Health and Social Services of James Bay. 2014. Annual Report. https://www.creehealth.org/sites/default/files/CBHSSJB\%20Annual\%2 OReport\%202013-2014\%20Lowres\%20for\%20Web.pdf

24. Cree Hunters and Trappers Income Security Board. 2018. Annual Report. http://www.osrcpc.ca/images/osrcpc/rapportannuel/2017_2018.pdf

25. Cree Nation Government. 2020. The Eeyou of Eeyou Istchee. Available: https://www.cngov.ca/community-culture/communities/.

26. Cwik M, Barlow A, Tingey L, Goklish N, Larzelere-Hinton F, Craig M, et al. Exploring risk and protective factors with a community sample of American Indian adolescents who attempted suicide. Arch Suicide Res. 2015;19(2): 172-89. https://doi.org/10.1080/13811118.2015.1004472.

27. Delormier T, Kuhnlein HV. Dietary characteristics of eastern James Bay Cree women. Arctic. 1999:52(2):182-7.

28. Depledge $M$, Bird $W$. The blue gym: health and wellbeing from our coasts. Mar Pollut Bull. 2009;58(7):947-8. https://doi.org/10.1016/j.marpolbul.2009.04. 019.

29. Dewailly E, Blanchet C, Gingras S, Lemieux S, Holub BJ. Cardiovascular disease risk factors and $\mathrm{n}-3$ fatty acid status in the adult population of James Bay Cree. Am J Clin Nutr. 2002;76(1):85-92. https://doi.org/10.1093/a $\mathrm{jcn} / 76.1 .85$.

30. Dewailly E, Blanchet C, Lemieux S, Sauvé L, Gingras S, Ayotte P, et al. N- 3 fatty acids and cardiovascular disease risk factors among the Inuit of Nunavik. Am J Clin Nutr. 2001;74(4):464-73. https://doi.org/10.1093/ajcn/ 74.4.464.

31. Dyall SC, Michael-Titus AT. Neurological benefits of omega-3 fatty acids. NeuroMolecular Med. 2008;10(4):219-35. https://doi.org/10.1007/s12017-0088036-z.

32. Dyerberg J, Bang $\mathrm{HO}$, Hiørne N. Fatty acid composition of the plasma lipids in Greenland Eskimos. Am J Clin Nutr. 1975;28(9):958-66. https://doi.org/10.1 093/ajcn/28.9.958.

33. Fischer CP. Interleukin-6 in acute exercise and training: what is the biological relevance. Exerc Immunol Rev. 2006;12:41.

34. Foulds HJ, Bredin SS, Warburton DE. The effectiveness of community based physical activity interventions with Aboriginal peoples. Prev Med. 2011;53(6): 411-6. https://doi.org/10.1016/j.ypmed.2011.09.008

35. Gabay C. Interleukin-6 and chronic inflammation. Arthritis Res Ther. 2006; 8(Suppl 2):S3. https://doi.org/10.1186/ar1917.

36. Ganesharajah C. Indigenous health and wellbeing: the importance of country. Native Title Research Unit, Australian Institute of Aboriginal and Torres Straight Islander Studies; 2009

37. Ganey PE, Roth RA. Concurrent inflammation as a determinant of susceptibility to toxicity from xenobiotic agents. Toxicology. 2001;169(3): 195-208. https://doi.org/10.1016/50300-483X(01)00523-6.

38. Garnett S, Sithole B. Sustainable northern landscapes and the nexus with indigenous health: healthy country, healthy people. Canberra: Land Water Australia; 2007.

39. Gates A, Hanning RM, Gates M, Skinner K, Martin ID, Tsuji L. Vegetable and fruit intakes of on-reserve first nations schoolchildren compared to Canadian averages and current recommendations. Int J Environ Res Public Health. 2012:9(4):1379-97. https://doi.org/10.3390/ijerph9041379.

40. Genest J, McPherson R, Frohlich J, Anderson T, Campbell N, Carpentier A, et al. 2009 Canadian cardiovascular society/Canadian quidelines for the diagnosis and treatment of dyslipidemia and prevention of cardiovascular 
disease in the adult-2009 recommendations. Can J Cardiol. 2009;25(10):56779. https://doi.org/10.1016/S0828-282X(09)70715-9.

41. Goldstein JL, Brown MS. The cholesterol quartet. Science. 2001;292(5520): 1310-2. https://doi.org/10.1126/science.1061815.

42. Graham H, Stamler LL. Contemporary perceptions of health from an indigenous (plains Cree) perspective. J Aborig Health. 2010;6(1):6-17.

43. Hatala AR, Njeze C, Morton D, Pearl T, Bird-Naytowhow K. Land and nature as sources of health and resilience among indigenous youth in an urban Canadian context: a photovoice exploration. BMC Public Health. 2020;20(538):1-14.

44. Holvoet P, Kritchevsky SB, Tracy RP, Mertens A, Rubin SM, Butler J, et al. The metabolic syndrome, circulating oxidized LDL, and risk of myocardial infarction in well-functioning elderly people in the health, aging, and body composition cohort. Diabetes. 2004;53(4):1068-73. https://doi.org/10.2337/ diabetes.53.4.1068.

45. Hopkins SE, Kwachka P, Lardon C, Mohatt GV. Keeping busy: a Yup'ik/Cup'ik perspective on health and aging. Int J Circumpolar Health. 2007;66(1):42-50. https://doi.org/10.3402/ijch.v66i1.18224.

46. Isaak CA, Marchessault G. Meaning of health: the perspectives of Aboriginal adults and youth in a northern Manitoba first nations community. Can J Diabetes. 2008;32(2):114-22. https://doi.org/10.1016/S1499-2671(08)22008-3.

47. Janelle A, Laliberté A, Ottawa U. Promoting traditions: an evaluation of a wilderness activity among first nations of Canada. Australas Psychiatry. 2009; 17(1_suppl):S108-11. https://doi.org/10.1080/10398560902948605.

48. JBNQA. 1975. JBNQA section 30: income security program for Cree hunters and trappers.

49. JBNQA. 1975. The James Bay and northern Quebec agreement (JBNQA).

50. Johnson-Down L, Labonte ME, Martin ID, Tsuji LS, Nieboer E, Dewailly E, et al. Quality of diet is associated with insulin resistance in the Cree (Eeyouch) indigenous population of northern Quebec. Nutr Metab Cardiovasc Dis. 2015; 25(1):85-92. https://doi.org/10.1016/j.numecd.2014.08.002.

51. Johnson-Down LM, Egeland GM. How is nutrition transition affecting dietary adequacy in Eeyouch (Cree) adults of northern Quebec, Canada? Appl Physiol Nutr Metab. 2013;38(3):300-5. https://doi.org/10.1139/apnm-2012-0167.

52. Kaholokula JK, Wilson RE, Townsend CKM, Zhang GX, Chen J, Yoshimura SR, et al. Translating the diabetes prevention program in native Hawaiian and Pacific islander communities: the PILI 'Ohana project. Transl Behav Med. 2013;4:149-59.

53. Kakekagumick KE, Naqshbandi Hayward M, Harris S, Saksvig B, Gittelsohn J, Manokeesic G, et al. Sandy lake health and diabetes project: a communitybased intervention targeting type 2 diabetes and its risk factors in a first nations community. Front Endocrinol. 2013:4:170.

54. Kasapis C, Thompson PD. The effects of physical activity on serum Creactive protein and inflammatory markers: a systematic review. J Am Coll Cardiol. 2005;45(10):1563-9. https://doi.org/10.1016/j.jacc.2004.12.077.

55. Katcher HI, Hill AM, Lanford JL, Yoo JS, Kris-Etherton PM. Lifestyle approaches and dietary strategies to lower LDL-cholesterol and triglycerides and raise HDL-cholesterol. Endocrinol Metab Clin N Am. 2009;38(1):45-78. https://doi.org/10.1016/j.ecl.2008.11.010.

56. Kuschner WG, D'Alessandro A, Wong H, Blanc PD. Dose-dependent cigarette smoking-related inflammatory responses in healthy adults. Eur Respir J. 1996;9(10):1989-94. https://doi.org/10.1183/09031936.96.09101989.

57. Lange KW. Omega-3 fatty acids and mental health. Global Health Journal. 2020;4(1):18-30. https://doi.org/10.1016/j.glohj.2020.01.004.

58. Lee AJ, O'Dea K, Mathews JD. Apparent dietary intake in remote Aboriginal communities. Aust J Public Health. 1994;18(2):190-7. https://doi.org/10.1111/ j.1753-6405.1994.tb00224.x

59. Lee ET, Jobe JB, Yeh J, Ali T, Rhoades ER, Knehans AW, et al. A cardiovascular risk reduction program for American Indians with metabolic syndrome: the balance study. J Prim Prev. 2012;33(4):187-96. https://doi. org/10.1007/s10935-012-0273-0.

60. Lee I-M, Paffenbarger RS Jr. Associations of light, moderate, and vigorous intensity physical activity with longevity: the Harvard alumni health study. Am J Epidemiol. 2000;151(3):293-9. https://doi.org/10.1093/oxfordjournals.aje.a010205.

61. Levitzky YS, Guo C-Y, Rong J, Larson MG, Walter RE, Keaney JF, et al. Relation of smoking status to a panel of inflammatory markers: the Framingham offspring. Atherosclerosis. 2008;201(1):217-24. https://doi.org/1 0.1016/j.atherosclerosis.2007.12.058.

62. Liberda EN, Zuk AM, Tsuji L. Complex contaminant mixtures and their associations with intima-media thickness. BMC Cardiovasc Disord. 2019; 19(1):289. https://doi.org/10.1186/s12872-019-1246-5.

63. Lines $L-A$, Jardine $C G$, Yellowknives Dene First Nation Wellness Division. Connection to the land as a youth-identified social determinant of indigenous peoples' health. BMC Public Health. 2019;19(1):176. https://doi. org/10.1186/s12889-018-6383-8.

64. Lucas M, Dewailly É, Blanchet C, Gingras S, Holub BJ. Plasma n-3 fatty acids and psychological distress in Aboriginal Cree Indians (Canada). Public Health Nutr. 2009;12(12):2343-51. https://doi.org/10.1017/S1368980009004935.

65. Maas J, Verheij RA, Groenewegen PP, de Vries S, Spreeuwenberg P. Green space, urbanity, and health: how strong is the relation? J Epi Community Health. 2006;60(7):587-92. https://doi.org/10.1136/jech.2005.043125.

66. Maple-Brown $\perp$, Brimblecombe J, Connelly PW, Harris SB, Mamakeesick M, Zinman B, et al. Similarities and differences in cardiometabolic risk factors among remote Aboriginal Australian and Canadian cohorts. Diabetes Res Clin Pract. 2013;100(1):133-41. https://doi.org/10.1016/j.diabres.2012.12.017.

67. Mensink RP, Katan MB. Effect of dietary trans fatty acids on high-density and low-density lipoprotein cholesterol levels in healthy subjects. N Engl J Med. 1990;323(7):439-45. https://doi.org/10.1056/NEJM199008163230703.

68. Michell R, Popham F. Greenspace, urbanity and health: relationship in England. J Epi Community Health. 2007;61(8):681-3. https//doi.org/10.1136/jech.2006.053553.

69. Milburn MP. Indigenous nutrition: using traditional food knowledge to solve contemporary health problems. Am Indian Q. 2004;28(3):411-34. https://doi. org/10.1353/aiq.2004.0104.

70. Mitchell R, Popham R. Effect of exposure to natural environment on health inequalities: an observational population study. Lancet. 2008;372(9650): 1655-60. https://doi.org/10.1016/S0140-6736(08)61689-X.

71. Moriarity RJ, Liberda EN, Tsuji LJ. Subsistence fishing in the Eeyou Istchee (James Bay, Quebec, Canada): a regional investigation of fish consumption as a route of exposure to methylmercury. Chemosphere. 2020;258:127413.

72. Moriarity RJ, Liberda EN, Tsuji US. Using a geographic information system to assess local scale methylmercury exposure in nine communities of the Eeyou Istchee territory (James Bay, Quebec, Canada). Environ Res. 2020;191:110147.

73. Muala A, Rankin G, Sehlstedt M, Unosson J, Bosson JA, Behndig A, et al. Acute exposure to wood smoke from incomplete combustion - indications of cytotoxicity. Part Fibre Toxicol. 2015;12(1):33. https://doi.org/10.1186/s12 989-015-0111-7.

74. Nieboer E, Dewailly E, Egeland GM, Chateau-Degat M-L, Bonnier-Viger Y. Technical report of Eastmain and Wemindji; 2011.

75. Nieboer E, Dewailly E, Johnson-Down L, Sampasa-Kanyinga H, ChateauDegat M-L, Egeland GM, et al. Nituuchischaayihtitaau Aschii Multicommunity Environment-and-Health Study in Eeyou Istchee 2005-2009: Final Technical Report. In: Nieboer E, Robinson E, Petrov K, editors. Public Health Report Series 4 on the Health of the Population. Chisasibi, QC: Cree Board of Health and Social Services of James Bay; 2013.

76. Nieboer, E. 2015. Overview of the study findings and reporting results environmental health contaminants program Nituuchischaayihtitaau Aschii. Presentation to Niskamoon 1 April 2015.

77. Nieboer E, VanSpronsen E. A needs and feasibility study for a comprehensive assessment of exposure to mercury [and other contaminants] and health status of Eeyouch of Eeyou Istchee. Hamilton: McMaster University; 2004.

78. Noreen W, Johnson-Down L, Jean-Claude M, Lucas M, Robinson E, Batal M. Factors associated with the intake of traditional foods in the Eeyou Istchee (Cree) of northern Quebec include age, speaking the Cree language and food sovereignty indicators. Int J Circumpolar Health. 2018;77(1):1536251. https://doi.org/10.1080/22423982.2018.1536251.

79. O'Dea K. Traditional diet and food preferences of Australian Aboriginal hunter-gatherers. Philos Trans R Soc Lond Ser B Biol Sci. 1991;334:233-41.

80. Ohsawa M, Okayama A, Nakamura M, Onoda T, Kato K, Itai K, et al. CRP levels are elevated in smokers but unrelated to the number of cigarettes and are decreased by long-term smoking cessation in male smokers. Prev Med. 2005;41(2):651-6. https://doi.org/10.1016/j.ypmed.2005.02.002.

81. Pal S, Haman F, Robidoux MA. The costs of local food procurement in two northern indigenous communities in Canada. Food Foodways. 2013;21 (2): 132-52. https://doi.org/10.1080/07409710.2013.792193.

82. Parker E, Meiklejohn B, Patterson C, Edwards K, Preece C, Shuter P, et al. Our games our health: a cultural asset for promoting health in indigenous communities. Health Promot J Austr. 2006;17(2):103-8. https://doi.org/10.1071/HE06103.

83. Patchell $B$, Edwards $K$. The role of traditional foods in diabetes prevention and management among native Americans. Curr Nutr Rep. 2014;3(4):340-4. https://doi.org/10.1007/s13668-014-0102-6.

84. Pedersen BK, Steensberg A, Fischer C, Keller C, Ostrowski K, Schjerling P. Exercise and cytokines with particular focus on muscle derived IL-6. Exerc Immunol Rev. 2001;7:18-31. 
85. Pepys MB, Hirschfield GM. C-reactive protein: a critical update. J Clin Invest. 2003;111:9.

86. Power E. Individual and household food insecurity in Canada: position of dietitians of Canada. Can J Diet Pract Res. 2005;66:43.

87. Pradhan AD, Manson JE, Rifai N, Buring JE, Ridker PM. C-reactive protein, interleukin 6, and risk of developing type 2 diabetes mellitus. Jama. 2001; 286(3):327-34. https://doi.org/10.1001/jama.286.3.327.

88. Proust F, Drescher O, Laouan-Sidi EA, Robinson E, Lucas M, Dewailly É. Omega-3 polyunsaturated fatty acid profiles and relationship with cardiometabolic risk factors in Cree (Eeyouch) of northern Quebec. Int J Circumpolar Health. 2016;75(1):30361. https://doi.org/10.3402/ijch. v75.30361.

89. Proust F, Johnson-Down L, Berthiaume L, Greffard K, Julien P, Robinson E, et al. Fatty acid composition of birds and game hunted by the eastern James Bay Cree people of Quebec. Int J Circumpolar Health. 2016;75(1): 30583. https://doi.org/10.3402/ijch.v75.30583.

90. Ramseyer VD, Garvin JL. Tumor necrosis factor-a: regulation of renal function and blood pressure. Am J Physiol-Ren Physiol. 2013;304(10):F123142. https://doi.org/10.1152/ajprenal.00557.2012.

91. R Core Team. R: A language and environment for statistical computing. $R$ Foundation for Statistical Computing, Vienna, Austria. 2019. https://www.Rproject.org/.

92. Redwood D, Schumacher MC, Lanier AP, Ferucci ED, Asay E, Heizer L, et al. Physical activity patterns of American Indian and Alaskan native people living in Alaska and the southwestern United States. Am J Health Promot. 2009;23(6):388-95. https://doi.org/10.4278/ajhp.071211130.

93. Redwood DG, Ferucci ED, Schumacher MC, Johnson JS, Lanier AP, Helzer LJ, et al. Traditional foods and physical activity patterns and associations with cultural factors in a diverse Alaska native population. Int J Circumpolar Health. 2008:67(4):335-48. https://doi.org/10.3402/ijch.v67i4.18346.

94. Rennie K, McCarthy N, Yazdgerdi S, Marmot M, Brunner E. Association of the metabolic syndrome with both vigorous and moderate physical activity. Int J Epidemiol. 2003;32(4):600-6. https://doi.org/10.1093/ije/dyg179.

95. Reynolds JE III, Wetzel DL, O'Hara TM. Human health implications of omega3 and omega- 6 fatty acids in blubber of the bowhead whale (Balaena mysticetus). Arctic. 2006;59(2):155-64.

96. Richmond CA, Ross NA. The determinants of first nation and Inuit health: a critical population health approach. Health Place. 2009;15(2):403-11. https:// doi.org/10.1016/j.healthplace.2008.07.004.

97. Robinson E, Gebre E, Pickering J. Effect of bush living on Aboriginal Canadians of the eastern James Bay region with non-insulin-dependent diabetes mellitus. Chronic Dis Can. 1995;16:144-8.

98. Robinson E, Torrie J, Harris R, Samchuck K-L, Choinière R. Health and what affects it in the Cree communities of Eeyou Istchee: a compilation of recent statistics; 2001.

99. Rowley KG, Daniel M, Skinner K, Skinner M, White GA, O'Dea K. Effectiveness of a community-directed 'healthy lifestyle' program in a remote Australian Aboriginal community. Aust N Z J Public Health. 2000;24(2):136-44. https:// doi.org/10.1111/j.1467-842X.2000.tb00133.x.

100. Ruxton CHS, Reed SC, Simpson MJA, Millington KJ. The health benefits of omega-3 polyunsaturated fatty acids: a review of the evidence. J Hum Nutr Diet. 2004;17(5):449-59. https://doi.org/10.1111/j.1365-277X.2004.00552.x.

101. Saghizadeh M, Ong JM, Garvey WT, Henry RR, Kern PA. The expression of TNF alpha by human muscle. Relationship to insulin resistance. J Clin Invest. 1996:97(4):1111-6. https://doi.org/10.1172/JCl118504.

102. Sawchuk CN, Charles S, Wen Y, Goldberg J, Forquera R, Roy-Byrne P, et al. A randomized trial to increase physical activity among native elders. Prev Med. 2008;47(1):89-94. https://doi.org/10.1016/j.ypmed.2008.03.011.

103. Schweigman K, Soto C, Wright S, Unger J. The relevance of cultural activities in ethnic identity among California native American youth. J Psychoactive Drugs. 2011;43(4):343-8. https://doi.org/10.1080/02791072.2011.629155.

104. Simopoulos AP. An increase in the Omega-6/Omega-3 fatty acid ratio increases the risk for obesity. Nutrients. 2016;8(3). https://doi.org/10.3390/ nu8030128.

105. Sproston NR, Ashworth JJ. Role of C-reactive protein at sites of inflammation and infection. Front Immunol. 2018;9. https://doi.org/10.3389/fimmu.2018.00754

106. Statistics Canada. 2019. Census profile, 2016 profile. Available: https:// www12.statcan.gc.ca/census-recensement/2016/dp-pd/prof/details/page. $\mathrm{cfm}$ ?Lang=E\&Geo $1=C S D \& C o d e 1=2499060 \& G e 02=P R \& C o d e 2=35 \&$ Data $=$ Count\&SearchText=Eeyou\%20Istchee\%20Baie-James\&SearchType= Begins\&SearchPR=01\&B1=All\&GeoLevel=PR\&GeoCode=2499060\&TABID=3.
107. Stone RAT, Whitbeck LB, Chen X, Johnson K, Olson DM. Traditional practices, traditional spirituality, and alcohol cessation among American Indians. J Stud Alcohol. 2006;67(2):236-44. https://doi.org/10.15288/jsa.2006.67.236.

108. Swain DP, Franklin BA. Comparison of cardioprotective benefits of vigorous versus moderate intensity aerobic exercise. Am J Cardiol. 2006;97(1):141-7. https://doi.org/10.1016/j.amjcard.2005.07.130.

109. Swiston JR, Davidson W, Attridge S, Li GT, Brauer M, van Eeden SF. Wood smoke exposure induces a pulmonary and systemic inflammatory response in firefighters. Eur Respir J. 2008;32(1):129-38. https://doi.org/10.1183/09031 936.00097707.

110. Tabas I. Cholesterol in health and disease. J Clin Invest. 2002;1 10(5):583-90. https://doi.org/10.1172/JCl0216381.

111. Tang K, Jardine CG. Our way of life: importance of indigenous culture and tradition to physical activity practices. Int J Indig Health. 2016;11(1):211-27. https://doi.org/10.18357/ijih111201616018.

112. Torrie J, Bobet E, Kishchuk E, Webster A. The evolution of health status and health determinants in the Cree region (Eeyou Istchee): Eastmain-1-a powerhouse and Rupert diversion Sectoral report: volume 2 detailed analysis; 2005.

113. Tsuji $\sqcup$, Tsuji SR, Zuk AM, Davey R, Liberda EN. Harvest programs in first nations of subarctic Canada: the benefits go beyond addressing food security and environmental sustainability issues. Int J Environ Res Public Health. 2020;17(21):8113.

114. Tsuji L, Manson H, Wainman BC, VanSpronsen EP, Shecapio-Blacksmith J, Rabbitskin T. Identifying potential receptors and routes of contaminant exposure in the traditional territory of the Ouje-Bougoumou Cree: land use and a geographical information system. Environ Monit Assess. 2007;127(1-3): 293-306. https://doi.org/10.1007/s10661-006-9280-z.

115. Tsuji $\sqcup$, Nieboer E. A question of sustainability in Cree harvesting practices: the seasons, technological and cultural changes in the western James Bay region of northern Ontario, Canada. Can J Native Stud. 1999;19:169-92.

116. Tsuji LS. Mandatory use of non-toxic shotshell for harvesting of migratory game birds in Canada: cultural and economic concerns. Can J Native Stud. 1998;18:19-36.

117. Tsuji $\sqcup$. Loss of Cree traditional ecological knowledge in the Western James Bay region of northern Ontario, Canada: a cases study of the sharp tailed grouse, Tympanuchus phasianellus. Can J Native Stud. 1996;16:283-92.

118. Tuomisto K, Jousilahti P, Sundvall J, Pajunen P, Salomaa V. C-reactive protein, interleukin- 6 and tumor necrosis factor alpha as predictors of incident coronary and cardiovascular events and total mortality. Thromb Haemost. 2006;95(03):511-8. https://doi.org/10.1160/TH05-08-0571.

119. Valera B, Dewailly E, Anassour-Laouan-Sidi E, Poirier P. Influence of n-3 fatty acids on cardiac autonomic activity among Nunavik Inuit adults. Int J Circumpolar Health. 2011;70(1):6-18. https://doi.org/10.3402/ijch.v70i1.17800

120. van den Berg A, et al. Green space as a buffer between stressful life events and health. Social Sci Med. 2010;70(8):1203-10. https://doi.org/10.1016/.socscimed.2010.01.002.

121. Von Schacky C, Harris WS. Cardiovascular benefits of omega-3 fatty acids. Cardiovasc Res. 2007;73:310-5.

122. Wajant $H$, Pfizenmaier $K$, Scheurich $P$. Tumor necrosis factor signaling. Cell Death Differ. 2003;10(1):45-65. https://doi.org/10.1038/sj.cdd.4401189.

123. Warbrick I, Wilson D, Boulton A. Provider, father, and bro-sedentary Māori men and their thoughts on physical activity. Int J Equity Health. 2016;15(1): 22. https://doi.org/10.1186/s12939-016-0313-0.

124. Watson J, Round A, Hamilton W. Raised inflammatory markers. BMJ. 2012; 344(feb03 1):e454. https://doi.org/10.1136/bmj.e454.

125. Wheeler BW, White M, Stahl-Timmins W, Depledge MH. Does living by the coast improve health and wellbeing?. Health place. 2012;18(5):1198-201.

126. Wilson K, Rosenberg MW. Exploring the determinants of health for first nations peoples in Canada: can existing frameworks accommodate traditional activities? Soc Sci Med. 2002;55(11):2017-31. https://doi.org/10.1 016/50277-9536(01)00342-2.

127. Wilson PW. High-density lipoprotein, low-density lipoprotein and coronary artery disease. Am J Cardiol. 1990;66(6):A7-A10. https://doi.org/10.1016/ 0002-9149(90)90562-F.

128. Yerrel P. National evaluation of BTCV's green Gym. Oxford: School of Health and Social Care, Oxford Brookes University; 2008.

129. Young TK, Nikitin YP, Shubnikov EV, Astakhova TI, Moffatt MEK, O'Neil JD. Plasma lipids in two indigenous Arctic populations with low risk for cardiovascular diseases. Am J Hum Biol. 1995;7(2):223-36. https://doi.org/10.1002/ajhb.1310070212.

\section{Publisher's Note}

Springer Nature remains neutral with regard to jurisdictional claims in published maps and institutional affiliations. 